\title{
The impact of guided student-generated questioning on chemistry achievement and self-efficacy of elementary preservice teachers
}

\author{
Christine Moseley ${ }^{1}$, Emily Bonner ${ }^{1}$, and Marilyn Ibey ${ }^{2}$ \\ ${ }^{1}$ Department of Interdisciplinary Learning and Teaching, University of Texas at San Antonio, San Antonio, USA \\ ${ }^{2}$ College of Sciences, Brown Mackie University, San Antonio, USA \\ For correspondence: christine.moseley@utsa.edu
}

\begin{abstract}
This study investigated the use of Guided Student-Generated Questioning (GSGQ) as a metacognitive instructional strategy to increase chemistry achievement and self-efficacy of elementary preservice teachers. The Chemistry SelfEfficacy Scale (CSES), modified from the Biology Self-Efficacy Scale (BSES), was used to determine elementary preservice teachers' self-reported confidence in understanding chemistry. Findings indicated that GSGQ was significantly related to an increase in achievement for the topics of water and solubility but not for the topics of chemical reactions or matter. In addition, the use of GSGQ was found not to be significantly related to chemistry selfefficacy.
\end{abstract}

Keywords: chemistry education, elementary preservice teachers, efficacy

\section{Introduction}

Inadequate content background in science (Franz \& Enochs, 1982) has been cited by elementary teachers as a major obstacle to effectively teaching science. This is a concern given the increasing importance of, and demand for, scientific literacy and competency in today's society (Bandura, 1997). According to Stevens and Wenner (1996),

Elementary teachers have been found to possess generally low level conceptual and factual knowledge as well as inadequate skills in the content area of science. General agreement exists that lack of such a background in science knowledge significantly contributes to hesitancy and possible inability to deliver effective science instruction in classroom settings. (p. 2)

In addition, elementary teachers' attitudes towards science are important in determining both the quality and quantity of science taught to children (Mulholland \& Wallace, 2001). Teachers have been shown to spend less time on subject areas, such as science, where their perceived selfefficacy is low (Enochs \& Riggs, 1990). Thus, assessment of content-specific efficacy beliefs is an important consideration in understanding preservice teachers' competence in a subject.

Several studies of preservice elementary teachers suggest that they generally have negative attitudes and a lack of confidence towards the teaching of physical science and chemistry concepts (Brigido, Bermejo, \& Mellado, 2012; Johnston \& Ahtee, 2006; Tosun, 2000; Yilmaz-Tuzun, 2008). These findings are relevant as negative beliefs about chemistry can lead to a dislike and avoidance of the subject (Danipog \& Ferido, 2011).These negative attitudes may be related to a lack of understanding of basic concepts in chemistry and/or prior negative experiences in school (Ahtee \& Johnston, 2006; Appleton, 
2006; Johnston \& Ahtee, 2006). Furthermore, preservice teachers often perceive chemistry concepts as largely abstract and, consequently, are unable to explain or apply them to real world situations (Çapa Aydin \& Uzuntiryaki, 2009).

Research also shows that attitudes about science influence abilities in science (Osborne, Simon, \& Collins, 2003). For preservice teachers, this relationship between attitudes and achievement can impact how they will teach in their future classrooms (Ramey-Gassert, Shrover, \& Staver, 1996). Several studies indicate that elementary preservice teachers are reluctant to teach science (Sherwood \& Westerack, 1983; Wenner, 1993), and that self-efficacy is a significant factor contributing to this reluctance (Wenner, 2001; Baker, 1991; Riggs and Enochs, 1990). Teachers with low perceived science teaching self-efficacy do not feel comfortable about their ability to practice or teach science and may resort to avoiding science. In contrast, teachers with high self-efficacy tend to teach science and apply effective instructional strategies in the classroom (Avery \& Meyer, 2012; Hechter, 2011).Thus, selfefficacy does influence how elementary preservice teachers view their role in the teaching of science and their potential success in that teaching (Finson, 2000).

In addition, there are studies reporting a direct relationship between students' use of metacognitive strategies and their self-efficacy beliefs about their performance (Anderson \& Nashon, 2007; Gourgey, 2001; Kleitman \& Stankov, 2007; Pintrich \& De Groot, 1990; Pintrich \& Garcia, 1991; Sungur, 2007). Gourgey (2001) stated that "metacognitive development might benefit not only their achievement, but their self-efficacy and motivation to learn as well" (p. 31).A review ofliterature also suggests there is a connection between effective metacognitive questioning strategies and academic achievement (Gall, 1984; Redfield \& Rousseau, 1981).

Guided Student-Generated Questioning (GSGQ), a metacognitive questioning strategy, has proven to be effective in increasing student achievement (King, 1991; Rosenshine, Meister, \& Chapman, 1996; Webb, 1989). However, little research has been done investigating the use of GSGQ with preservice teachers, especially at the elementary level. This study was designed to investigate how to improve elementary preservice teachers' academic achievement and efficacy towards the understanding of chemical concepts. More specifically, this study was conducted to investigate the impact of the use of GSGQ as a metacognitive instructional strategy on elementary preservice teachers' achievement and self-efficacy in chemistry.

\section{Theoretical Framework}

The premise that learning is socially constructed comes from the theory of social construction of knowledge whereby a person learns by revising old knowledge or constructing new knowledge with the help of peer interaction (Vygotsky, 1978). Information-processing theorists contend that students gain understanding when they construct knowledge or reconstruct existing knowledge with other students. This process allows new ideas to be associated with previous learning (Mayer, 1981, 1984).

According to Walsh and Sattes (2005), four aspects of learning - metacognition, question generation skills, attitudes, and self-efficacy - are interrelated. Guided Student-Generated Questioning (GSGQ) has been proven to be an effective metacognitive strategy in which students can formulate and answer content questions (Webb, 1989). Attitudes such as eagerness for knowledge and learning about the world foster student questioning and academic achievement. Self-efficacy is a person's confidence to carry out a task (Baldwin, Ebert-May, \& Burns, 1998) and the power to affect an outcome (Scott, 1996). Metacognitive questioning not only facilitates student learning but it also supports student self-efficacy (Pajares, 1996). The definition of metacognition includes the selfefficacy features of personal reflection with respect to knowledge and affective states and the mental processes that aid in cognition (Paris \& Winograd, 1990). 
Social cognitive theory, a unified theory of behavior change, is concerned with human agency and how people exercise some level of control over their own lives. The theory states that an individual's behavior is primarily learned through his or her observations of others as well as through interactions with the environment (Bandura, 1977). An individual's belief in his/her ability in performing a task (i.e. learning chemistry) influences behavior, including the amount of time and effort expended to achieve a task and persistence when confronting obstacles towards the achievement of that task (Pajares, 1996).Generally, students with high levels of self-efficacy believe that they will succeed in a task while students with low self-efficacy believe they will be unsuccessful in accomplishing that task (Scott, 1996). Students with high self-efficacy establish greater expectations for themselves, use diverse strategies in problem solving, and persevere longer to meet their goals (Bandura, 1997; Bandura, Barberanelli, Caprera, \& Pastorelli, 1996; Jinks \& Morgan, 1999; Pajares, 1996; Scott, 1996). As such, an individual's ability to succeed in an academic setting is closely related to his/her selfefficacy towards a specific academic subject, such as chemistry.

According to Bandura (1986), an individual's self-efficacy is influenced by four major sources of information:(a) prior experiences of mastery in performing a similar task, (b) vicarious learning opportunities wherein an individual sees another person similar in ability succeed at the task, (c) verbal persuasion by others to perform a task, particularly by a person who is competent in that task; and (d) emotional or physiological states while performing the task such as joy, stress, or fatigue. The effects of these four sources combined produce the overall self-efficacy of an individual in a given situation or context.

Self-efficacy is content or task specific, meaning that one's level of perceived ability changes depending on the task or situation and influenced by the four sources within the context of the specific task (Tschannen-Moran, Woolfolk, \& Hoy, 1998). As such, many researchers have demonstrated the direct relationship between self-efficacy and achievement in a given subject area (Hampton \& Mason, 2003; Multon, Brown, \& Lent, 1991; Pajares \& Miller, 1994; Shell, Colvin, \& Bruning, 1995). Specifically, scientific self-efficacy is predictive of scientific achievement (Andrew, 1998; House, 1993). Typically, students with higher self-efficacy in their ability to understand scientific concepts are more likely to engage in learning science than students with low self-efficacy who may tend to avoid science (McMillan \& Forsyth, 1991). Previous studies indicate that self-efficacy beliefs significantly predict academic achievement in physical science (Andrew, 1998) and chemistry (Fenel \& Scheel, 2005; Kan \& Akbas, 2006; Lalich, Taylor, \& Pribyl, 2006; Zusho, Pintrich, \& Coppola, 2003).

\section{Pilot Study}

The goal of the research study was to investigate the use of GSGQ in impacting elementary preservice teachers' efficacy beliefs and academic achievement in chemistry. An initial review of the literature did not yield an established survey instrument to adequately address this goal. Thus, a new instrument, the Chemistry Self-Efficacy Scale (CSES), was developed by modifying an existing survey and piloted prior to the research study.

The instrument development process involved the use of content expert feedback with respect to content and language of items within the survey and the use of appropriate reliability and factor analyses to examine the structure of the survey. Following standard measurement criteria for developing valid and reliable measures, the items on the CSES were subjected to expert reviews and pilot testing. 


\section{Chemistry Self- Efficacy Scale}

The Chemistry Self-Efficacy Scale (CSES) is a modification of the Biology Self-Efficacy Scale (BSES),a proven valid and reliable instrument that measures the biology self-efficacy of non-biology majors (Baldwin, Ebert-May, \& Burns, 1998). In developing the BSES, an item pool was developed from an analysis of the literature in scientific literacy (American Association for the Advancement of Science, 1990; Biological Science Curriculum Study, 1993; National Research Council, 1997; National Science Foundation, 1996). The domains of scientific literacy identify the aspects of science that individuals should know, do, experience, and value as citizens (Bybee, 1997). The BSES items chosen reflected the scientific domains of confidence in reading, summarizing, and critiquing biology concepts; writing and thinking with a scientific approach; and applying information learned in class to real-life experiences.

The BSES consists of 23 items rated on a five-point Likert scale: 1 strongly agree to 5 strongly disagree. A principal factoring solution was used to analyze the underlying factor structure of student responses. Factor 1 represents the scientific domain of perceived confidence in writing and critiquing biological concepts, as well as using analytical skills. Factor 2 relates to perceived confidence in generalizing skills learned and using a scientific approach to solving problems. Factor 3 addresses the scientific domain of perceived confidence in an ability to apply biological concepts and skills to everyday events. Internal consistency reliability coefficients (Cronbach's alpha test) were found to be 0.88 (Factor 1), 0.88 (Factor 2), and 0.89 (Factor 3) for the three domains of biological literacy (Baldwin, Ebert-May, \& Burns, 1998).

The Chemistry Self-Efficacy Scale (CSES) was modified from the BSES by substituting the words "chemical" or "chemistry" for "biological" or "biology." The CSES uses the same format as the BSES, a five-point reversed-scored Likert scale. Initially, a panel of three content experts with expertise in both chemistry and science education pedagogy reviewed the items on the CSES to assess content and face validity for instrument clarity and "offer concrete suggestions for improving the measure" (Rubio, Berg-Weger, Tebb, Lee, \& Rauch, 2003, p. 95).The expert panel consisted of one university faculty in chemistry and two faculty in science education. Each panel expert was asked to review each item for clarity and relevance to the research and provide any additional feedback regarding how to improve items and the overall instrument.

To further determine content, face, and construct validity and reliability, a pilot of the CSES survey was administered to 92 elementary preservice teachers the semester prior to the research study. A principal component factor analysis was performed to identify the underlying responses on both the pre-survey and the post-survey (see Table 1 for the pre-survey factor analysis and Table 2 for the post-survey factor analysis). Based on the psychometric properties of the BSES, the items on the CSES are grouped into the same three factor domains of the BSES.

The first factor - Methods of Chemistry - contains eight items that refer to students' confidence in writing and analyzing their ideas in chemistry and utilizing analytical skills. For example, Question 19 on the survey asks, "How confident are you that you could critique an experiment described in a chemistry textbook?" The second factor - Generalization to Other Science Courses and Analyzing Data contains nine items that refer to students' confidence in generalizing skills acquired in a chemistry course and confidence in using a scientific problem-solving approach. For example, Question 8 asks, "How confident are you that you will be successful in this chemistry course?" The third factor Application of Chemical Concepts and Skill-contains six items that refer to students' confidence in their ability to apply chemistry concepts and skills to everyday life. For example, Question 1 asks, "How confident are you that after reading an article about a chemistry experiment you could write a summary of its main points?" 
Table 1. Factor Loadings for Exploratory Factor Analysis of CSES Pre-survey Components (Varimax Rotation)

\begin{tabular}{lccc}
\hline CSES Question & Component 1 & Component 2 & Component 3 \\
\hline 1 & .270 & .624 & .300 \\
2 & .345 & .564 & .242 \\
3 & .208 & .777 & .159 \\
4 & .295 & .407 & .525 \\
5 & .018 & .467 & .594 \\
6 & .202 & .805 & .242 \\
7 & .189 & .328 & .800 \\
8 & .671 & .301 & .223 \\
9 & .284 & .649 & .284 \\
10 & .319 & .196 & .809 \\
11 & .733 & .265 & .243 \\
12 & .503 & .646 & .155 \\
13 & .597 & .145 & .583 \\
14 & .825 & .198 & .218 \\
15 & .491 & .465 & .346 \\
16 & .471 & .234 & .685 \\
17 & .790 & .235 & .114 \\
18 & .540 & .568 & .217 \\
19 & .629 & .467 & .306 \\
20 & .726 & .312 & .230 \\
21 & .430 & .620 & .237 \\
22 & .509 & .473 & .409 \\
23 & .228 & .622 & .464 \\
\hline
\end{tabular}

Table 2. Factor Loadings for Exploratory Factor Analysis of CSES Post-survey Components (Varimax Rotation)

\begin{tabular}{lccc}
\hline CSES Question & Component 1 & Component 2 & Component 3 \\
\hline 1 & .656 & .312 & .317 \\
2 & .507 & .340 & .495 \\
3 & .436 & .553 & .307 \\
4 & .724 & .342 & .386 \\
5 & .496 & .633 & .092 \\
6 & .405 & .687 & .246 \\
7 & .778 & .328 & .162 \\
8 & .575 & .355 & .536 \\
9 & .593 & .494 & .316 \\
10 & .762 & .240 & .309 \\
11 & .377 & .365 & .638 \\
12 & .507 & .528 & .438 \\
13 & .560 & .375 & .480 \\
14 & .280 & .225 & .836 \\
15 & .352 & .717 & .280 \\
16 & .676 & .319 & .400 \\
17 & .316 & .205 & .810 \\
18 & .154 & .614 & .572
\end{tabular}


Component 1 corresponded to Factor 2: Generalization to Other Science Courses and Analyzing Data, and had a percent of variance of 22.071 in the pre-survey scale and 24.577 in the post-survey scale. Component 2 corresponded to Factor 3: Application of Chemical Concepts and Skills, and had a percent of variance of 21.666 in the pre-survey scale and 23.835 in the post-survey scale. Component 3 corresponded to Factor 1: Methods of Chemistry, and had a percent of variance of 26.726 in the presurvey scale and 23.154 in the post-survey scale.

The same three factors, including the same question items per factor as in the original BSES, loaded together after orthogonal rotation. These three factors were correlated to a moderate degree, but still remained independent constructs. These results suggest that the new CSES was valid for use in the research study and can be used as a tool in chemistry instruction for elementary preservice teachers.

Internal consistency reliability coefficients of Factors 1, 2, and 3 were then determined using Cronbach's alpha test. The indices of reliability for Factors 1, 2, and 3 in the pre-survey were 0.91, 0.92 , and 0.89 , respectively. The indices of reliability for Factors 1, 2, and 3 in the post-survey were $0.92,0.94$, and 0.92 , respectively.

\section{Research Study}

The research study was conducted the semester following the pilot study to investigate the impact of the use of GSGQ as a metacognitive instructional strategyon elementary preservice teachers' achievement and self-efficacy in chemistry. The Chemistry Self-Efficacy Scale (CSES)was used to measure self-efficacy, and the Chemistry Achievement Test constructed from questions on the state standardized science exam measured chemistry achievement.

\section{Participants}

The setting for the pilot and research studies was a large, urban, federally-recognized Hispanicserving institution in the south central United States. The participants in the research study $(n=72)$ included two convenient nonrandom groups of preservice elementary teachers $(91 \%$ female; $75 \%$ age 19-23; 52\% Hispanic) enrolled in two sections of an undergraduate college physical science course for non-majors. Seventy-two participants completed both pre and post chemistry achievement tests $(n=30 /$ experimental group; $n=42 /$ control group) and 61 participants completed both pre and posttests of the CSES ( $n=28 /$ experimental group; $n=33 /$ control group).

To validate the use of the modified survey instrument, the CSES was piloted as a pre and post-survey to 92 preservice elementary education teachers enrolled in a required physical science course the semester prior to the research study. In order to ensure the validity and reliability of the pilot CSES, the similarities between the pilot and study groups were established. Table 3 displays demographic characteristics of the participants in both the pilot and research studies both and these data suggest that the populations were substantially similar. 
Table 3. Demographic Characteristics as a Percentage of the Study Sample

\begin{tabular}{lcc}
\hline Characteristic & Pilot Group & Study Group \\
$\qquad \mathrm{N}$ & 92 & 72 \\
$\begin{array}{l}\text { Gender } \\
\text { Female }\end{array}$ & 91.4 & 94.4 \\
Age & & \\
$\quad$ 19-23 years of age & 75.3 & 76.4 \\
$\begin{array}{l}\text { Ethnicity } \\
\text { Non-Anglo }\end{array}$ & 48.4 & 56.9 \\
\hline
\end{tabular}

\section{Context of the Study}

The research study investigated the use of Guided Student Generated Questioning (GSGQ), a metacognitive questioning strategy involving socially constructed learning (King, 1991; Rosenshine, Meister, \& Chapman, 1996; Webb, 1989). GSGQ involves giving students question stems or question starters that they individually answer and then share the questions with their peers in a small group setting. These question stems help students generate their own content questions at various cognitive levels (Cline, 2000).

According to King (1992), GSGQ is an effective metacognitive strategy where connect new content and information with prior knowledge and experiences (Oakes \& Lipton, 1999). GSGQ also involves peer-mediated learning, a process where "students attain higher levels of thinking when encouraged to develop skill in asking their own questions and when provided with more opportunities for dialogue with the classmates about the questions posed and conclusions derived from information" (Hunkins, 1976, p. 3). Thus, students are motivated to ask more complex questions of each other (Rosenshine, Meister, \& Chapman, 1996). Explaining and defending one's thinking to peers improve the overall understanding of a concept as students have to elaborate and reorganize their thoughts to make them understandable (Bargh \& Schul, 1980).

The implementation of the GSGQ strategy in the research study occurred over a four week period and was embedded within the chemistry portion of a physical science course designed for elementary preservice teachers. The course includes the study of the fundamental laws that govern the universe, including mechanics, thermodynamics, electromagnetism, and quantum theory, and how these relate to physics and chemistry. Class discussions and activities are hands-on, inquiry-based, utilizing whole-group discussions, cooperative learning groups, and individual projects. Lecture and laboratory activities are integrated and designed around the learning cycle format (exploration, concept formation, and expansion), emphasizing the science process skills in discussions and demonstrations as they relate to the fields of physics and chemistry.

One class section of the course was selected as the control group, using researcher-prepared chemistry questions. The other class section was selected as the treatment group, using studentgenerated chemistry questions from prepared question stems. In each of these two classes, the preservice teachers were randomly grouped into triads. The same instructor taught both sections of the course. The only difference in instruction between the control and treatment groups was the procedure used to develop the chemistry discussion questions. The lectures, class activities, and demonstrations were exactly the same in both groups for the same amount of time. The questioning 
sessions were done at the end of the lesson in each group. The question stems in the control group were developed into complete content questions by the researcher prior to the topic lecture, whereas the same question stems were developed into complete content questions by the preservice teachers in the treatment group.

The instructor who taught both class sections was initially trained by the researcher in the questioning review procedures to ensure that the study was conducted consistently and systematically. Then, the preservice teachers in both classes, facilitated by the same instructor, practiced the questioning review procedures for one hour to become familiar with the routine. Beginning the following week for one three-hour class session per group per week for the next four weeks, a different topic in chemistry was taught identically in both classes. The four chemistry topics selected were matter, chemical reactions, solutions and water. Each week, the preservice teachers, in groups of three, followed the topic lecture with one of the questioning review activities: GSGQ strategy for the experimental class and researcher-prepared questions for the control class.

In the class with the prepared questions (control group), each triad participant received three of nine prepared questions at random. Then the preservice teachers individually answered (in writing) their three questions, using lecture notes if needed for reference. After all the answers to the prepared questions were completed, each group member posed the three questions orally to the other group members to answer and discuss. In the class using GSGQ (treatment group), each participant of the triad received three question stems at random. Each preservice teacher individually created, answered in writing, and shared with group members three content topic questions from the given question stems, using the provided lecture notes if needed for reference. In both the control and treatment group, students were given 20 minutes to develop, answer, and share the questions. Students in each group were allowed to give feedback to the peer presenter and ask further questions of the presenter for clarification.

In both class sections prior to the study, the preservice teachers were trained in how to generate questions from the following given question stems:

- How would you make use of ___ ?

- How does __ apply to ___ ?

- Predict what would happen if

- Why do you think $?$

- What is the reason for ___ ?

- What relationship exists between ?

- How would you test ___ ?

- What is the significance of ___ ?

- What is the most important $?$

The following questions from the lesson on Solubility provide an example of the two types of questioning strategies. A preservice teacher in the GSGQ class generated the following question from a stem (bolded): What relationship exists between polar/ionic and nonpolar solutes and solvents? Then 
the preservice teacher responded to the question she created from the stem (underlined) with the following answer: The relationship is that they determine how much of the solute will dissolve in a solvent or whether the substance will dissolve at all. In contrast, a preservice teacher in the non GSGQ class was given the following researcher-prepared question using the same stem (bolded): What relationship exists between solute and solvent? The preservice teacher then responded to this researcher-generated question with the following answer: The solute is dissolved and the solvent does the dissolving. The openended questions generated by the preservice teachers from researcher-prepared questions stems in the GSGQ class and the researcher-prepared questions of the non GSGQ class were comparable in content and cognitive levels.

\section{Chemistry Achievement Test}

Academic achievement in chemistry was assessed by using sixteen questions from the state standardized science test. These questions include basic chemistry concepts that elementary preservice teachers seeking state teacher certification in early childhood to sixth grade need to know and understand. Four each of the sixteen questions relate to each of the subtopics of matter, chemical reactions, solubility, and water.

The content validity of the Chemistry Achievement Test (CAT) is based on content alignment to the state science standards. The No Child Left Behind Act (NCLB) of 2001 required states to ensure the alignment of their assessment tests to the existing content curricula. Consequently, content specialists involving teachers, test development specialists, and state officials developed valid test item types, objectives, and guidelines

The CAT, according to the state education department not only has content validity because it reasonably samples content from the state curriculum, but also concurrent validity because it reasonably relates to other measures of the same construct (Texas Education Agency, 2008). Concurrent validity was demonstrated in the Higher Education Readiness Study of 2007, the Pearson study of 2007, and the Grade Correlation Study of 2008. The correlation values for the Higher Education Readiness Study were 0.57 (SAT 1 verbal vs. state exam ELA), 0.79 (SAT 1 math vs. state exam math), 0.79 (ACT math vs. state exam math), and 0.58 (ACT English vs. state exam ELA).

\section{Data Collection}

The CSES and the CAT were used as pre/post surveys to assess any significant change in chemistry self-efficacy and academic achievement. The preservice teachers completed both pre-surveys one week prior to the first topic lecture. The two post-surveys were administered one week after the fourth lecture, which was five weeks after the administration of the pre-surveys.

\section{Data Analysis}

All data were analyzed using IBM SPSS Statistics for Windows Version 21.0 (2012). An independent samples t-test analysis between GSGQ and non-GSGQ participant groups' chemistry achievement and self-efficacy mean scores was conducted. Independent t-tests were also used to determine the change between the two groups on the three factors of self-efficacy and the four topics of chemistry content.

The Nonequivalent Control Group Design (shown in Figure1) was used in this study (Wiersma, 1969). Both groups of participants were initially given two pretests - the CSES and CAT - to determine equivalence between the experimental and control groups. Then, only the experimental group was 
given the treatment. After the treatment, both groups were given two posttests to determine the effect of the treatment on the experimental group.

\begin{tabular}{lcll}
\hline $\begin{array}{l}\text { Group } \\
\text { Week } 1\end{array}$ & $\begin{array}{c}\text { Pretest/Question Training } \\
\text { Weeks 2-5 }\end{array}$ & $\begin{array}{l}\text { Treatment } \\
\text { Week 6 }\end{array}$ & Posttest \\
\hline $\begin{array}{l}\text { Experimental } \\
\text { Control }\end{array}$ & O & X & O \\
\hline
\end{tabular}

Figure 1. Nonequivalent Control Group Design

\section{Results}

Validation of the CSES

The participant groups of preservice elementary teachers in both the pilot study and the research study were similar in gender, age and ethnicity. In the pilot study, the CSES was found by principal component analysis with orthogonal rotation and Cronbach's alpha test to be a valid and reliable chemistry self-efficacy scale with similar component factors to the original BSES. The results of the pilot study suggested that the new CSES was valid for use in the research study and can be used as a tool in chemistry instruction and assessment for elementary preservice teachers.

\section{GSGQ and Chemistry Achievement}

There was no significant difference $(\mathrm{p}<0.05)$ between the CATpretest mean scores of the non-GSGQ and GSGQ groups. However, there was a significant difference $(\mathrm{p}<0.05)$ between the overall CAT posttest mean scores of non-GSGQ and GSGQ groups (see Table 4). The mean score of the CAT posttest of the experimental group taught with GSGQ was significantly higher than the mean score of the CAT posttest of the control group not taught with GSGQ.

Table 4. Comparison of Posttest Chemistry Achievement between GSGQ and non-GSGQ Groups

\begin{tabular}{llllll}
\hline GSGQ & & & \multicolumn{3}{c}{ non-GSGQ } \\
$\mathrm{N}$ & $\mathrm{M}$ & $\mathrm{SD}$ & $\mathrm{N}$ & $\mathrm{M}$ & $\mathrm{SD}$ \\
\hline 30 & 55.50 & 17.99 & 42 & 41.81 & 18.41 \\
\hline
\end{tabular}

Note: equal variances assumed.

The posttest mean scores for each chemistry topic were higher for the GSGQ group than the nonGSGQ group (see Table 5). However, for only the topics of solubility and water were the posttest mean scores of the GSGQ group significantly higher $(p<0.05)$ than the posttest mean scores of the non-GSGQ group.

Table 5. Comparison of Mean Correct Answer Cognitive Posttest Topics Groups

\begin{tabular}{|c|c|c|c|c|c|c|c|}
\hline \multirow[b]{2}{*}{ Topic } & \multicolumn{3}{|c|}{ GSGQ } & \multicolumn{4}{|c|}{ non-GSGQ } \\
\hline & $\mathrm{N}$ & $\mathrm{M}$ & SD & $\mathrm{N}$ & $\mathrm{M}$ & SD & $t(d f)$ \\
\hline Matter & 30 & 3.07 & 1.20 & 42 & 2.59 & 1.23 & $1.62(70)$ \\
\hline Ch. Reactions & 30 & 1.97 & 1.00 & 42 & 1.52 & 1.06 & $1.79(70)$ \\
\hline Solubility & 30 & 2.30 & 1.06 & 42 & 1.02 & 1.09 & $5.00(70)$ \\
\hline Water & 30 & 1.80 & 1.16 & 42 & 1.19 & 1.04 & $2.33(70)$ \\
\hline
\end{tabular}




\section{GSGQ and Chemistry Self-Efficacy}

There was no significant difference $(p<0.05)$ between the overall self-efficacy mean scores of both groups (see Table 6). Also, there was no significant difference between the mean scores of the three factors of chemistry self-efficacy.

Table 6.Comparison of Posttest Self-Efficacy Mean Scores between GSGQ and non-GSGQ Groups

\begin{tabular}{|c|c|c|c|c|c|c|}
\hline \multirow{2}{*}{\multicolumn{2}{|c|}{ GSGQ }} & \multicolumn{5}{|c|}{ non-GSGQ } \\
\hline & & $\mathrm{N}$ & $\mathrm{M}$ & $\mathrm{SD}$ & $\mathrm{N} \mathrm{M}$ & $\mathrm{SD} \quad \mathrm{t}(\mathrm{df})$ \\
\hline Overall & & 28 & 60.861 & 17.7633 & 58.1421 .84 & $.527(59)$ \\
\hline $\begin{array}{l}\text { Concept \& Skill } \\
\text { Application }\end{array}$ & 28 & 15.04 & 4.93 & 33 & $15.79 \quad 5.41$ & $1-.563(59)$ \\
\hline $\begin{array}{l}\text { Methods of } \\
\text { Chemistry }\end{array}$ & 28 & 21.29 & 6.47 & 33 & $21.27 \quad 7.13$ & $3.007(59)$ \\
\hline $\begin{array}{l}\text { Generalization } \\
\text { \& Analyzing Dat }\end{array}$ & 28 & 23.93 & 7.31 & 33 & $24.18 \quad 8.08$ & $3-.127(59)$ \\
\hline
\end{tabular}

\section{Discussion and Implications}

The theoretical basis for the study on metacognitive questioning strategies and cognitive achievement is grounded in the idea that students gain understanding when they construct knowledge or reconstruct existing knowledge in a social construct (Mayer, 1981, 1984). Incorporating metacognition into levels of questioning has resulted in the development of several successful metacognitive instructional questioning strategies that improve student achievement. Guided Student-Generated Questioning (GSGQ) is one of these strategies.

This study quantitatively examined the effect of GSGQ on chemistry achievement and student selfefficacy of elementary preservice teachers enrolled in a required physical science college class. The metacognitive strategy was implemented in the experimental group and statistical analysis of pre/post cognitive scores and self-efficacy scores were analyzed for significant differences.

For the elementary preservice teachers, GSGQ significantly increased overall chemistry achievement $(p<0.05)$ for the topics of water and solubility but did not cause a significantly increase in chemistry achievement for the topics of chemical reactions and matter. However, even though there was not a significant increase in the mean scores for the topics of chemical reactions and matter in the GSGQ group, the scores did increase from pre to post survey. The authors of this study agree with Bereiter and Scardamalia (1989) and Rosenshine, Meister and Chapman(1996) that GSGQ can be an effective instructional strategy to involve preservice teachers in their own learning, allowing them to focus attention on and regulate their learning processes (King, 1991). Preservice teachers should be encouraged to create their own relevant content questions from question stems rather than use teacher-generated questions. In this way, they can reflect on what content they understand, what they do not understand, and what they need to study (King, 1991).

The findings of this study suggest that teacher educators could create learning environments that more effectively develop the metacognitive skills of preservice teachers in order to increase their chemistry achievement. In the literature, various researchers have documented that metacognition can be enhanced during classroom instruction (Adey, Shayer \& Yates, 1989; Baird \& Northfield, 1992; 
Beeth, 1998; Georghiades, 2000). Guided instruction that facilitates metacognitive instructional processes can be used in the chemistry classroom to provide a student-centered learning environment in which preservice teachers have the opportunity to be more reflective about their own learning.

There was no significant difference between the chemistry self-efficacy post-survey mean scores of both groups. The chemistry self-efficacy remained at a consistent "fairly confident" or moderate level (means between 60.96 and 69.43) throughout the study. In other words, the preservice teachers' beliefs about their ability to understand chemistry did not significantly increase in spite of increased achievement in chemistry. Moreover, each of the three self-efficacy factor mean scores showed no significant difference between the GSGQ and non-GSGQ groups. These findings contradict the literature on self-efficacy as a predictor of scientific achievement and need to be further investigated.

Researchers have previously reported that student self-efficacy is a good predictor of academic achievement (Bandura, 1997; Britner, 2008; Gwilliam \& Betz, 2001; Kupermintz, 2002; Schunk, 1996). Therefore, it is important to find instructional strategies that increase student self-efficacy. Several possible reasons that self-efficacy did not increase in this study could be related to the four informational sources of self-efficacy. Mastery experiences (Bandura (1997) tend to be the most influential as they provide the most authentic evidence of success. Bandura argues that information about self-efficacy derived from a performance will depend on aspects of the task and self-efficacy beliefs already held. It is likely that these elementary preservice teachers have had limited prior mastery experiences in chemistry. Efficacy beliefs already held are not easily changed, so that positive experiences that are inconsistent with existing beliefs tend to be minimized.

Vicarious experiences also influence efficacy beliefs when individuals learn new knowledge or skills by observing others perform the task. This is especially true for activities in which individuals must assess their ability by comparing themselves with others. Self-efficacy is usually increased if one compares well against others and lowered if one compares less favorably with people in similar situations (Bandura, 1982). Self-efficacy is especially sensitive to vicarious experience in situations where people are inexperienced or uncertain about their own capabilities (Bandura, 1997). This might have been the case in this study, resulting in little change in efficacy.

Two other sources of information influencing self- efficacy includesocial persuasion and affective state of mind. Social persuasion can have a negative effect on self-efficacy if feedback given to the individual is negative (Bandura, 1997). Authentic, truthful, and realistic encouragements tied to a specific learning experience lead people to exert greater effort and are thus, more likely to succeed (Pintrich, 2003). Affective state of mind refers to an individual's emotional state and can be used to judge personal capabilities in achieving a task. If individuals experience excessive nervousness, anxiety, or fear of failure, they are likely to doubt their ability to succeed (Bandura, 1997).In this study, there were opportunities for peer feedback, but this feedback may not have been positive enough to overcome prior negative attitudes and change beliefs.

Another consideration in the lack of change of self-efficacy is the fact that only four topics in chemistry were addressed in this study, and these topics were addressed over a short period of time (4 weeks), with only one three-hour class period for each topic. Thus, more hands-on experiences over a longer period of time, encouragement by mentors, and repeated success in chemistry achievement for elementary preservice teachers are recommended and should lead eventually to greater confidence in learning chemistry concepts.

Using the CSES to measure change in self-efficacy can provide chemistry educators and researchers with an assessment tool to determine which tasks and teaching strategies best increase chemistry selfefficacy. It can also be used by teacher educators to gain an understanding of their preservice 
teachers' confidence in learning chemistry concepts and consequently, assist them in the planning and designing of curricula.

Like Thomas, Pedersen, and Finson (2001), the authors of this study believe that changes in preservice teachers' personal chemistry self-efficacy beliefs are unlikely to occur "without a great deal of purposeful, systematic inquiry about their personal theories, beliefs, and practice" (p. 328). The CSES is offered as one methodological tool to assist preservice teachers in analyzing and reflecting on their personal beliefs about chemistry. According to Paris and Winograd (1990), this reflection has two benefits: “(a) it transfers responsibility for monitoring learning from teachers to students themselves, and (b) it promotes positive self-perceptions, affect, and motivation among students. In this manner, metacognition provides personal insights into one's own thinking and fosters independent learning" (p. 15).

\section{Future Studies}

As previously stated, self-efficacy is directly influenced by the four sources of information as related to a specific task. Thus, the context of the learning environment is important to the development of self-efficacy towards a subject and consequently, academic achievement in that subject. Topics for further investigation might involve the ways in which teacher characteristics impact self-efficacy among students. To what degree does the self-efficacy of the teacher towards the subject being taught impact the self-efficacy of the students? How does the classroom environment affect efficacybeliefs? What types of instructional methods promote positive self-efficacy beliefs? Cooperative learning, the use of higher level questions, article analysis, concept maps, position papers done in a group format, and daily classroom writing or speaking activities are instructional strategies known to be effective in increasing biology self-efficacy(Bandura, Barberanelli, Caprera, \& Pastorelli, 1996). Research needs to be conducted to determine if these instructional strategies are also effective in increasing chemistry self-efficacy.

Investigations into the relationships between personal efficacy and demographics, such as gender, age, grade level, and ethnicity are needed. This study involved a population of non-chemistry majors consisting of 90\% females. The study done by Baldwin, Ebert-May, and Burns (1998), using the BSES, consisted of a 3:1 female to male ratio. To ensure that the CSES will function similar to the BSES, another study should be conducted with a higher percentage of male preservice teachers.

In the present study, data were collected over a short period of time (five weeks). The relationship between self-efficacy beliefs and academic achievement in chemistry should be studied longitudinally. How do the efficacy beliefs of preservice teachers develop and change over time? How do efficacy beliefs influence elementary preservice teachers' future teaching efficacy regarding chemistry concepts? Further research should focus on ways to increase personal self-efficacy. A future qualitative study of students' perceptions toward chemistry related to this current study would give insight into the underlying effects of the four main sources of self-efficacy on chemistry achievement.

According to Pajares (2003), "teachers and schools are responsible for helping students develop their competence and confidence as students progress through school." Bandura (1986) argued that:

Educational practices should be gauged not only by the skills and knowledge they impart for present use but also by what they do to children's beliefs about their capabilities, which affects how they approach the future. Students who develop a strong sense of self-efficacy are well equipped to educate themselves when they have to rely on their own initiative. (p. 417)

Teachers who provide children with challenging tasks and meaningful activities that can be mastered, support these efforts, believe in their students, and convey their beliefs help ensure that their students 
will develop a strong sense of efficacy (Mills \& Clyde, 1991). We think that teacher educators should do the same. Personal self-efficacy ultimately becomes a way of thinking. Because teachers are influential in helping their students develop the self-beliefs that will serve them throughout their lives, it is imperative that teachers themselves have a strong sense of accomplishment and selfefficacy in the subjects in which they teach.

There are some limitations of the current study. First, this study relied on the data obtained by two surveys. Surveys are efficient tools to gather data from samples in a short period of time; however, they provide limited information about the participants' thoughts or beliefs. Observations and/or interviews could be used as sources of more in-depth data. Second, the sample size of the results limits the generalizability of the results.

\section{References}

Adey, P., Shayer, M., \& Yates, C. (1989). Cognitive acceleration: The effects of two years of intervention in science classes. In P. Adey, J. Bliss, J. Head, \& M. Shayer (Eds.), Adolescent development and school science (pp. 240-247). London: Falmer Press.

Ahtee, M., \& Johnston, J. (2006). Primary student teachers' ideas about teaching a physics topic. Scandinavian Journal of Educational Research, 50(2), 207-219.

American Association for the Advancement of Science (1990). The liberal art of science. Washington,DC: AAAS.

Anderson, L.W., \& Krathwohl, D.R. (Eds.). (2001). A taxonomy for learning, teaching, and assessing: A revision of Bloom's taxonomy of educationalobjectives. New York, NY: Addison Wesley Longman.

Anderson, D., \& Nashon, S. (2007). Predators of knowledge construction: Interpreting students' metacognition in an amusement park physics program. Science Education, 91(2), 298-320.

Andrew, S. (1998). Self-efficacy as a predictor of performance in science. Journal of Advanced Nursing, 27, 596-603. doi: 10.1046/j.1365-2648.1998.00550x

Appleton, K. (2006). Science pedagogical content knowledge and elementary school teachers. In K. Appleton (Ed.), Elementary science teacher education: International perspectives on contemporary issues and practice. Mahwah, NJ: Association for Science Teachers and Laurence Erlbaum.

Avery, L. \& Meyer, D. (2012). Teaching science as science is practiced: Opportunities and limits for enhancing pre-service elementary teachers' self-efficacy for science and science teaching. School Science and Mathematics. 112(7), 395-409.

Baird, J. R., \& Northfield, J. R. (1992). Learning from the PEEL experience. Melbourne, Victoria: Monash University Press.

Baker, D. R. (1991). A summary of research in science education - 1989. Science Education,75, 1-35.

Baldwin, J. A., Ebert-May, D., \& Burns, D. J. (1998). The development of a college biology

self-efficacy instrument for non-majors. Science Education, 83(4), 397-408.

Bandura, A. (1977). Self-efficacy: Toward a unifying theory of behavioral change. Psychological Review, 2, 191-215.

Bandura, A. (1986). Social foundations of thought and action: A social cognitive theory. Englewood Cliffs, NJ: Prentice Hall.

Bandura, A. (1997). Self-efficacy: The exercise of control. New York, NY: Freeman.

Bandura, A., Barberanelli, C., Caprera, G. V., \& Pastorelli, C. (1996). Multifaceted impact of self-efficacy on academic functioning. Child Development, 67(3), 1206-1222.

Bargh, J. A., \& Schul, Y. (1980). On the cognitive benefits of teaching. Journal of Educational Psychology, 72(5), 592-604. doi: 10.1037/0022-0663.72.5.593.

Beeth, M. E. (1998). Facilitating conceptual change leaning: The need for teachers to support metacognition. Journal of Science Teacher Education, 9(1), 49-61.

Bereiter, C., \& Scardamalia, M. (1989). Intentional learning as a goal of instruction. In L.

B. Resnick (Eds.), Knowing, learning, and instruction: Essays in honor of Robert

Glaser (pp. 361-392). Hillsdale, NJ: Lawrence Erlbaum Associates. Biological Science Curriculum Study (1993). An instructional model for science education in developing biological literacy. Colorado Springs, CO: BSCS.

Brigido, M., Bermejo, M. L. \& Mellado, V. (2012). Self-efficacy and emotions in prospective primary education science teachers. In Bruguière, C., Tiberghien, A. \& Clément, P. (Eds.), E-Book Proceedings of the ESERA 2011 Conference: Science Learning and Citizenship Part 12, (pp. 19-24). Lyon, France: European Science Education Research Association.

Britner, S. L. (2008). Motivation in high school science students: A comparison of gender differences in life, physical, and earth science classes. Journal of Research in Science Teaching, 45(8), 955-970.

Bybee, R. (1997). Achieving scientific literacy. Portsmouth, NH: Heinemann/Reed Elsevier.

Çapa Aydin, Y.\&Uzuntiryaki, E. (2009). Development and psychometric evaluation of the high school chemistry self-efficacy scale. Educational and Psychological Measurement, 69(5), 868-880.

Cattell, R. B. (1966). The scree test for the number of factors. Multivariate Behavioral Research, 1, 245.

Cline, R.W. (2000). The teachability and utilization of a metacognitive strategy in distance learning classrooms. (Doctoral dissertation). Retrieved from Dissertation \& Theses Full Text. (2000. 9999083)

Cohen, J. (1988). Statistical power analysis for the behavioral sciences (2nd ed.). Hillsdale, NJ: Lawrence Earlbaum.

Danipog, D. L. \& Ferido, M. B. (2011). Using art-based chemistry activities to improve students' conceptual understanding in chemistry. Journal of Chemical Education, 88(12), 1610-1615. 
Enochs, L. \& Riggs, I. (1990). Further development of an elementary science teaching efficacy belief instrument: A preservice elementary scale. Science Education, 74(6), 625-637.

Fenel, H. \& Scheel, K. (2005). Engaging students: An examination of the effects of teaching strategies on self-efficacy and course climate in a non-majors physics course. Journal of College Science Teaching, 35(1), 20-25.

Finson, K.D. (2000, January). Investigating preservice elementary teachers' self-efficacy relative to self-image as a science teacher. Paper presented at the Annual Meeting of the Association for the Education of Teachers in Science, Akron, $\mathrm{OH}$.

Franz, J.R., \& Enochs, L.G. (1982). Elementary school science: State certification requirements in science and their implications. Science Education. 66, 287-292.

Gall, M. (1984). Synthesis of research of teachers' questioning. Educational Leadership, 42(3), 40-47.

Georghiades, P. (2000). Beyond conceptual change learning in science education: Focusing on transfer, durability and metacognition. Educational Research, 42(2), 119-139.

Gourgey, A. F. (2001). Metacognition in basic skills instruction. In H. J. Hartman (Eds.), Metacognition in learning and instruction (pp. 17-32). Netherlands: Kluwer Academic Publishers.

Gwilliam, L. R., \& Betz, N. E. (2001).Validity of measures of math- and science-related self-efficacy for African Americans and European Americans. Journal of Career Assessment, 9(3), 261-281.

Hampton, N.Z., \& Mason, E. (2003). Learning disabilities, gender, sources of self-efficacy, self-efficacy beliefs, and academic achievement in high school students. Journal of School Psychology, 41(2), 101-112. doi: 10.1016/50022-4405(03)00028-1

Hechter, R. P. (2011). Changes in pre-service elementary teachers' personal science teaching efficacy and science teaching outcome expectancies: The influence of context. Journal of Science Teacher Education, 22, 187-202.

House, J.D. (1993). Cognitive motivational predictors of science achievement. International Journal of Instructional Media, 20(2), 155-162.

Hunkins, F. P. (1976). Involving students in questioning. Boston: Allyn \& Bacon.

Jinks, J., \& Morgan, V. (1999). Children's perceived academic self-efficacy: An inventory scale. The Clearing House, 72(4), 224230.

Johnston, J. \& Ahtee, M. (2006). Comparing primary student teachers' attitudes, subject knowledge and pedagogical content knowledge needs in a physics activity. Teaching and Teacher Education, 22, 503-512.

Kan, A., \& Akbas, A. (2006). Affective factors that influence chemistry achievement and the power of this factors to predict chemistry achievement. Journal of Turkish Science Education, 3(1), 76-85.

King, A. (1991). Reciprocal peer-questioning for learning from lectures. Education Digest, 57(1), 59-62.

King, A. (1992). Comparison of self-questioning, summarizing and note-taking-review as strategies for learning from lectures. American Educational Research Journal, 29(2), 303-32.

Kleitman, S., \&Stankov, L. (2007). .Self-confidence and metacognitive processes. Learning and Individual Differences, 17, $161-173$.

Kupermintz, H. (2002). Affective and conative factors as aptitude resources in high school

science achievement. Educational Assessment, 8(2), 123-137.

Lalich, I. J., Taylor, M. J., \& Pribyl, J. R. (2006, April). Identification of the correlationbetween student self-efficacy and final course percentage in a general chemistrycourse. Paper presented at a conference at Minnesota State University, Mankato, MN.

Mayer, R. E. (1981). The psychology of how novices learn computer programming. Computing Surveys, 13(1), 121-141.

Mayer, R. E. (1984). Aids to prose comprehension. Educational Psychologist, 19(1), 30-42.

McMillan, J. H., \& Forsyth, D. R. (1991). What theories of motivation say about why learners learn.In R. Menges \& M. Svinicki (Eds.), College teaching: From theory to practice. San Francisco,CA: Jossey-Bass.

Mills, H., \& Clyde, J. A. (1991). Children's success as readers and writers: It's the teacher's beliefs that make the difference. Young Children, 46(2), 547-559.

Mulholland, J. \& Wallace, J. (2001). Teacher induction and elementary science teaching: enhancing self-efficacy. Teaching and Teacher Education, 17 (2001) 243-261.

Multon, K.D., Brown, S. D., \& Lent, R. W. (1991). Relation of self-efficacy beliefs to academic outcomes: A meta-analytic investigation. Journal of Counseling Psychology, 38(1), 30-38.

National Research Council (1997). Science teaching reconsidered: A handbook. Washington, DC: National Academy Press.

National Science Foundation (1996). Shaping the future: New expectations for undergraduate education in science, mathematics, engineering, and technology. Directorate for Education and Human Resources. Arlington, VA: NSF.

Oakes, J., \& Lipton, M. (1999). Teaching to change the world. Boston, MA: McGraw-Hill College.

Osborne, J., Simon, S., \& Collins, S. (2003). Attitudes towards science, a review of the literature and its implications. International Journal of Science Education, 25(9), 1049-1079.

Pajares, F. (1996). Self-efficacy beliefs in academic settings. Review of Educational Research,66, 543-579.

Pajares, F. (2003). Self-efficacy beliefs, motivation, and achievement in writing: A review of the literature. Reading $\mathcal{E}$ Writing Quarterly, 19, 139-158.

Pajares, F., \& Miller, M.D. (1994). The role of self-efficacy and self-concept beliefs in mathematical problem solving: A path analysis. Journal of Educational Psychology, 86(2), 193-203.

Paris, S. G., \& Winograd, P. (1990). How metacognition can promoteacademic learning and instruction. In B. F. Jones \& L. Idol (Eds.),Dimensions of thinking and cognitive instruction (pp. 15-51). Hillsdale,NJ: Erlbaum.

Pintrich, P.R. (2003). A motivational science perspective on the role of student motivation in learning and teaching contexts. Journal of Educational Psychology, 95(4), 667-686. 
Pintrich, P. R., \& De Groot, E. (1990). Motivational and self-regulated learning components of classroom academic performance. Journal of Educational Psychology, 82(1), 33-40.

Pintrich, P. R., \& Garcia, T. (1991).Student goal orientation and self-regulation in the college classroom. In M. L. Maehr \& P. R. Pintrich (Eds.), Advances in motivation and achievement: Goals and self-regulatory processes (pp. 371-402). Greenwich, CT: JAI Press.

Ramey-Gassert, L., Shroyer, M. G., \& Staver, J. R. (1996). A qualitative study of factors influencing science teaching self-efficacy of elementary level teachers. Science Education, 80(3), 283-315.

Redfield, D. L., \& Rousseau, E. W. (1981). A meta-analysis of experimental research on teacher questioning behaviour. Review of Educational Research, 51, 237-245.

Riggs, L., \& Enochs, L. (1990). Toward the development of an elementary education teachers' science teaching efficacy belief instrument. Science Education 74, 625-637.

Rosenshine, B., Meister, C., \& Chapman, S. (1996). Teaching students to generate questions: A review of the intervention studies. Review of Educational Research, 66(2), 181-221.

Rubeck, M., \& Enochs, L. (1991, April). A path analytic model of variables that influence science and chemistry teaching selfefficacy and outcome expectancy in middle school science teachers. Paper presented at the annual meeting of the National Association of Research in Science Teaching, Lake Geneva, WI.

Rubio, D. M., Berg-Weger, M., Tebb, S. S., Lee, E. S., \& Rauch, S. (2003). Objectifying content validity: Conducting a content validity study in social work research. Social Work Research, 27(2), 94-104.

Schunk, D. H. (1996). Goal and self-evaluative influences during children's cognitive skill learning. American Educational Research Journal, 33(2), 359-382.

Schraw, G. (2001). Promoting general metacognitive awareness. In H. Hartman (Ed.), Metacognition in learning and instruction: Theory, research and practice (pp. 3-16). Norwell, MA: Kluwer Academic Press.

Scott, J. (1996). Self-efficacy: A key to literacy learning. Reading Horizons, 36(Jan/Feb), 195-213.

Shell, D.F., Colvin, C., \& Bruning, R.H. (1995). Self-efficacy, attributions, and outcome expectancy mechanisms in reading and writing achievement: Grade-level and achievement level differences. Journal of Educational Psychology, 87(3), 386398.doi: 10.1037/0022-0663.87.3.386.

Sherwood, R. D. \& Westerack, M. E. (1983). A factor analytic study of the state-trait anxiety inventory utilized with preservice elementary teachers. Journal of Research in Science Teaching 20, 225-229.

Stevens, C. and Wenner, G. (1996), Elementary preservice teachers' knowledge and beliefs regarding science and mathematics. School Science and Mathematics, 96: 2-9.

Sungur, S. (2007). Modeling the relationships among students' motivational beliefs, metacognitive strategy use, and effort regulation. Scandinavian Journal of Educational Research, 51(3), 315-326.

Taasoobshirazi, G. \& Glynn, S. M. (2009).College students solving chemistry problems: A theoretical model of expertise. Journal of Research in Science Teaching, 46(10), 1070-1089.

Tabachnick BG, Fidell LS. (2007). Using Multivariate Statistics. Boston, MA: Pearson Education Inc.

Texas Education Agency. (2008). Retrievedfrom www.tea.state.tx.us/index3.aspx?id=4326\&menu_id793.

Thomas, J., Pederson, J., \& Finson, K. (2001). Validating the draw-a-science-teacher-test checklist (DASTT-C): Exploring mental models and teacher beliefs. Journal of Science Teacher Education, 12(3), 295-310.

Tosun, T. (2000). The beliefs of preservice elementary teachers toward science and science teaching. School Science and Mathematics, 100(7), 374-379.

Tschannen-Moran, M., Woolfolk, A., \& Hoy, W.K. (1998). Teacher efficacy: capturing an elusive construct. Review ofEducational Research, 68(2),202-248. doi: 10.2307/1170754

Uzuntiryaki, E., \& Çapa Aydin, Y. (2008). Development and validation of chemistry self-efficacy scale for college students. Research in Science Education, 39(4), 539-551.

Vygotsky, L.S. (1978). Mind in society: The development of higher psychological processes. Cambridge, MA: Harvard University Press.

Walsh J.A., \& Sattes, B.D. (2005). Quality questioning: Research-based practice to engage every learner. Thousand Oaks, California: Corwin Press.

Webb, N, M. (1989). Peer interaction and learning in small groups. International Journal of Educational Research, 13(1), 21-40. doi: 10.1016/0883-0355(89)90014

Wenner, G. (1993). Relationship between science knowledge levels and beliefs toward science instruction held by preservice elementary teachers. Journal of Science Education and Technology, 2, 461-468.

Wenner, G. (2001). Science and mathematics efficacy beliefs held by practicing and prospective teachers: A 5-year perspective. Journal of Science Education and Technology, 10(2), 181-187.

Wiersma, W. (1969). Research methods in education: An introduction. New York, NY: Allyn\& Bacon.

Yilmaz-Tuzun, O. (2008). Preservice elementary teachers' beliefs about science teaching. Journal of Science Teacher Education, 19(2), 183-204.

Zusho, A., Pintrich, P.R., \& Coppola, B. (2003). International Journal of Science Education, 25(9), 1081-1094. 